\title{
Fishbone foreign body ingestion in duodenal papilla: a cause of abdominal pain resembling gastric ulcer
}

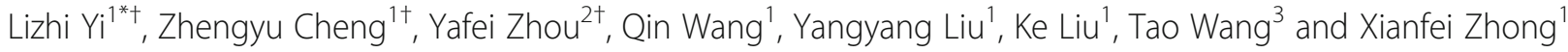

\begin{abstract}
Background: Foreign body ingestion is a common clinical problem. The upper esophagus is the most common site of foreign body, accounting for more than $75 \%$ of all cases, but cases with a foreign body in the duodenal papilla or common bile duct are rarely reported.
\end{abstract}

Case presentation: Herein, we report a rare case that a patient's abdominal pain resembling gastric ulcer was caused by a $3 \mathrm{~cm}$ long fishbone inserted into the duodenal papilla.

Conclusion: Fishbone inserted into the duodenal papilla can cause an abdominal pain resembling gastric ulcer. Endoscopy is useful for the diagnosis and treatment of fishbone ingestion in clinical.

Keywords: Fishbone, Foreign body, Duodenal papilla, Abdominal pain

\section{Background}

Foreign body ingestion is a common diagnosis in clinical practice. Patients with foreign body ingestion usually present with odynophagia, dysphagia, the feeling of being stuck, chest or abdominal pain, vomiting and other symptoms [1]. The upper esophagus is the most common site of foreign body, accounting for more than $75 \%$ of all cases, but cases with a foreign body in the duodenal papilla or in the common bile duct are very rare $[1,2]$. Here, for the first time we reported a $3 \mathrm{~cm}$ long fishbone inserted into the duodenal papilla, which resulted in the abdominal pain resembling gastric ulcer.

\section{Case presentation}

A 52-year-old woman visited our hospital because of intermittent abdominal pain for half a month. She had no symptoms of melena, hematemesis or fever. The pain

\footnotetext{
*Correspondence: 651218437@qq.com

'Lizhi Yi, Zhengyu Cheng and Yafei Zhou contributed equally to this work.

'Department of Gastroenterology, People's Hospital of Leshan, Leshan, Sichuan, People's Republic of China

Full list of author information is available at the end of the article
}

was localized to upper abdomen and regularly aggravated after taking meals. This patient had a gastric ulcer with bleeding cured 20 years ago. Besides that, she has no other significant medical history. Physical examination showed that there was a mild tenderness but not rebound tenderness in the upper abdomen. Owing to the history of gastric ulcer, a gastroscopy was performed, which indicated something protruding from the duodenal papilla with a patchy erosion below (Fig. 1a and b). Since the object was covered by mucus and bile, it was difficult to distinguish what it was. Based on this situation, we came up with the method that using a foreign body forceps to gently clamp the object. Thereafter, it was clamped and slowly pulled out from the duodenal papilla. To our surprise, it was a fishbone about $3 \mathrm{~cm}$ long (Fig. 2). After removing the foreign body, a small amount of blood was observed on the duodenal papilla (Fig. 1c), but there was no persistent bleeding after washing it with normal saline. After the operation, patient's abdominal pain was relieved. She told us that she did eat fish half a month ago, but had no sense of being stuck. Subsequently, we suggested to carry out a CT

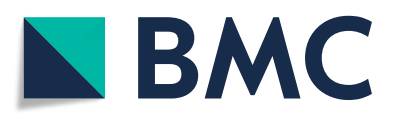

(c) The Author(s). 2020 Open Access This article is licensed under a Creative Commons Attribution 4.0 International License, which permits use, sharing, adaptation, distribution and reproduction in any medium or format, as long as you give appropriate credit to the original author(s) and the source, provide a link to the Creative Commons licence, and indicate if changes were made. The images or other third party material in this article are included in the article's Creative Commons licence, unless indicated otherwise in a credit line to the material. If material is not included in the article's Creative Commons licence and your intended use is not permitted by statutory regulation or exceeds the permitted use, you will need to obtain permission directly from the copyright holder. To view a copy of this licence, visit http://creativecommons.org/licenses/by/4.0/. The Creative Commons Public Domain Dedication waiver (http://creativecommons.org/publicdomain/zero/1.0/) applies to the data made available in this article, unless otherwise stated in a credit line to the data. 

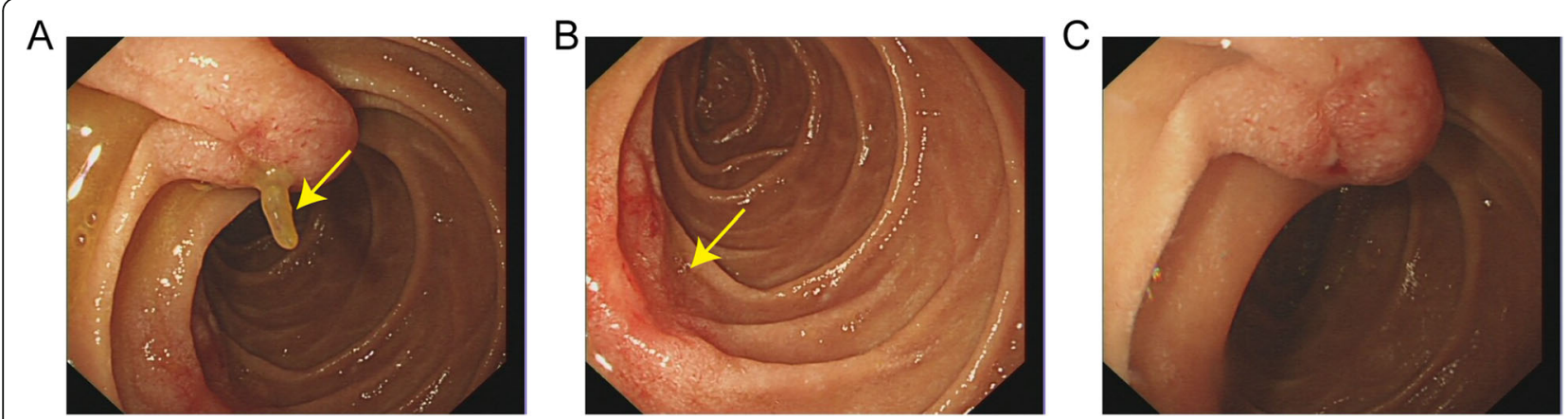

Fig. 1 Endoscopic images before and after the removal of the foreign body: a Gastroscopy revealed something protruding from the duodenal papilla; $\mathbf{b}$ Patchy erosion below the duodenal papilla; $\mathbf{c}$ The duodenal papilla after extraction of the foreign body

scan of the abdomen because the fishbone had inserted into the duodenal papilla deeply for a long time, but the patient refused. One week later after the operation, the patient did not feel any discomfort and the abdominal pain was disappeared.

\section{Discussion and conclusion}

Fishbone is the most common foreign body among the population in Asia, the Mediterranean, and other coastal countries due to dietary habits [3]. Generally, it is recommended to remove fishbone before they pass through the pylorus, otherwise $15-35 \%$ of them may perforate the intestine [4]. The frequent lodging sites of fishbones in the upper digestive tract are palatine tonsil, base of the tongue, valleculae, the piriform sinus and the first narrow area of esophagus [5]. It has been reported in a case that a toothpick was inserted into the common bile duct [6], but fishbone inserted into the duodenal papilla was never reported. Since the fishbone in our case was long and thin and very similar to a toothpick, we speculated that the fishbone might also be inserted into the common bile duct.

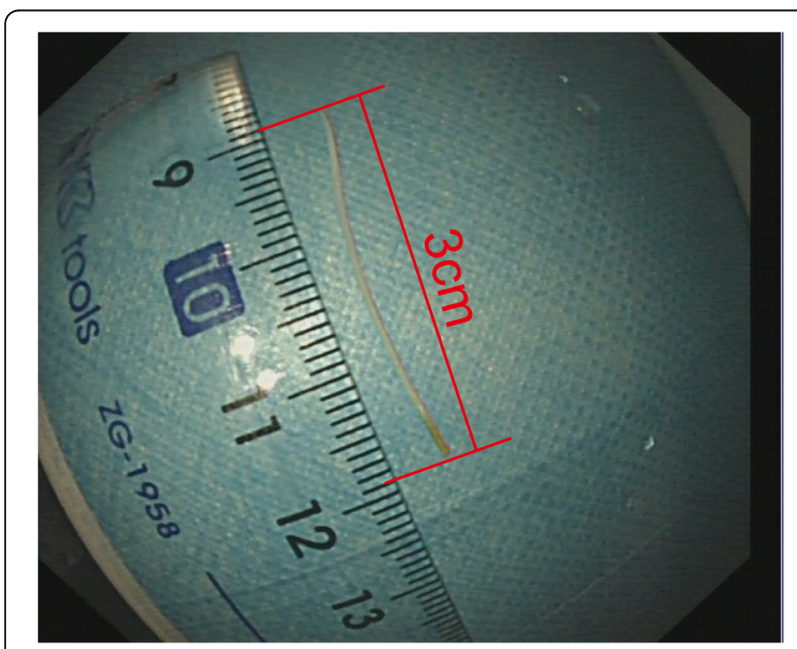

Fig. 2 The fishbone successfully removed was about $3 \mathrm{~cm}$ long
Patients with duodenal papillary foreign body may go through the acute stage and the chronic stage. At the acute stage, if there is a clear history of foreign body ingestion, the diagnosis is quick but the treatments may be different. Ouzhu M reported a dental prosthesis impacted in the duodenal papilla, which was then removed through endoscopy [7]. Dias $\mathrm{R}$ also reported a metal pin removed by a surgical exploration of the duodenum [8]. If the patients do not report a history of foreign body ingestion, both diagnosis and treatment will be difficult. Some foreign bodies may cause acute pancreatitis [9], while others may lead to ascending cholangitis [10]. In addition, at the acute stage, some foreign bodies might be misdiagnosed as choledocholithiasis [6]. At the chronic stage, some foreign bodies might form biliary stones, which may cause the cholangitis [11] or cholecystitis [12]. Moreover, the foreign body may also cause chronic pancreatitis [13].

Although the fishbone was successfully and safely removed using a foreign body forceps, we still believed that endoscopic ultrasonography might be a good choice before the operation. Because the patchy erosion under the foreign body suggested that the fishbone might penetrate deeply. Lack of experience, we didn't realize it was needed until we saw the length of the fish bone. This was also what we learned from this case. In addition, liver enzymes tests were also recommended because the patient had a biliary foreign body. It was worth noting that gastroscopy should be the first examination for patients with foreign bodies. If the endoscopist failed to carefully observe the duodenal papilla, the patient's diagnosis would be tortuous.

In our case, the patient's pain was localized to upper abdomen and was regularly aggravated after taking meals, which was similarly to the pain caused by a gastric ulcer. We suspected that it may be related to the increased duodenal peristalsis after meals. And the patchy erosion below the duodenal papilla was very likely caused by the swaying fishbone. Therefore, the patients with regular abdominal pain, not only the stomach but also the duodenal papilla are needed to be carefully examined. 


\section{Abbreviation}

$\mathrm{CT}$ : Computed Tomography

\section{Acknowledgements}

We thank Xiaoli Ren for her assistance in providing imaging consultation.

\section{Authors' contributions}

LZY, ZYC, YFZ, QW, YYL, KL, TW and XFZ collected the information of the patient and wrote the manuscript. LZY was also a major contributor in writing the manuscript. All authors have read and approved the final manuscript.

\section{Funding}

Not applicable.

\section{Availability of data and materials}

Not applicable.

\section{Ethics approval and consent to participate}

A case report is intended to develop information to be shared for medical and educational purposes and do not meet the definition of "research". Ethical approval was not necessary. Written informed consent was obtained from the patient.

\section{Consent for publication}

Written informed consent was obtained from the patient for publication of this Case report and any accompanying images. A copy of the written consent is available for review by the Editor of this journal.

\section{Competing interests}

The authors have disclosed that they have no significant relationships with, or financial interest in, any commercial companies pertaining to this article.

\section{Author details}

'Department of Gastroenterology, People's Hospital of Leshan, Leshan, Sichuan, People's Republic of China. ${ }^{2}$ Department of Anesthesiology, People's Hospital of Leshan, Leshan, Sichuan, People's Republic of China. ${ }^{3}$ Department of Radiology, People's Hospital of Leshan, Leshan, Sichuan, People's Republic of China.

Received: 27 February 2020 Accepted: 28 September 2020

Published online: 02 October 2020

\section{References}

1. Bekkerman M, Sachdev AH, Andrade J, Twersky Y, labal S. Endoscopic Management of Foreign Bodies in the gastrointestinal tract: a review of the literature. Gastroenterol Res Pract. 2016;2016:8520767.

2. Aydın E, Bent S, Ayan B. Atypical presentation of multiple foreign body ingestion. APSP J Case Rep. 2017:8(1):7.

3. Klein A, Ovnat-Tamir S, Marom T, Gluck O, Rabinovics N, Shemesh S. Fish bone foreign body: the role of imaging. Int Arch Otorhinolaryngol. 2018; 23(1):110-5.

4. Sugawa $\mathrm{C}$, Ono H, Taleb M, Lucas CE. Endoscopic management of foreign bodies in the upper gastrointestinal tract: a review. World J Gastrointest Endosc. 2014;6(10):475-81.

5. Kim JP, Kwon OJ, Shim HS, Kim RB, Kim JH, Woo SH. Analysis of clinical feature and management of fish bone ingestion of upper gastrointestinal tract. Clin Exp Otorhinolaryngol. 2015:8:261-7.

6. Brunaldi VO, Brunaldi MO, Masagao R, Silva C, Masuda H, Brunaldi JE. Toothpick inside the common bile duct: a case report and literature review. Case Rep Med. 2017;2017:5846290.

7. Ouzhu M, Wu C, Ye L, Dawa J, Hu B. Endoscopic removal of dental prosthesis impacted in the duodenal papilla. Endoscopy. 2019;51(1):E10-1.

8. Dias R, Dharmaratne P. Ingested foreign body in the common bile duct. J Indian Assoc Pediatr Surg. 2012;17(1):31-2.

9. Dabadie A, Roussey M, Betremieux P, Gambert C, Lefrancois C, Darnault P. Acute pancreatitis from a duodenal foreign body in a child. J Pediatr Gastroenterol Nutr. 1989;8(4):533-5.

10. Zonnebelt S, Wolberg W. Ascending cholangitis secondary to a chicken bone lodged at the ampulla of Vater. Am J Surg. 1981;141(5):610-1.
11. Yu M, Huang B, Lin $Y$, et al. Acute obstructive cholangitis due to fishbone in the common bile duct: a case report and review of the literature. BMC Gastroenterol. 2019;19(1):177 Published 2019 Nov 7.

12. Kelly MD, Hugh TB. Cherry stalk in the common bile duct. Aust N Z J Surg. 1993;63(7):571-4.

13. Tiller M, Schepp W, Gundling F, Tuerck J. Chronic pancreatitis caused by a swallowed orthodontic device. Endoscopy. 2014:46(Suppl 1 UCTN):E667-8.

\section{Publisher's Note}

Springer Nature remains neutral with regard to jurisdictional claims in published maps and institutional affiliations.

\section{Ready to submit your research? Choose BMC and benefit from}

- fast, convenient online submission

- thorough peer review by experienced researchers in your field

- rapid publication on acceptance

- support for research data, including large and complex data types

- gold Open Access which fosters wider collaboration and increased citations

- maximum visibility for your research: over $100 \mathrm{M}$ website views per year

At BMC, research is always in progress.

Learn more biomedcentral.com/submission 